\title{
INFLUENCE OF NONNATIVE AND NATIVE UNGULATE BIOMASS AND SEASONAL PRECIPITATION ON VEGETATION PRODUCTION IN A GREAT BASIN ECOSYSTEM
}

\author{
Linda C. Zeigenfuss ${ }^{1,5}$, Kathryn A. Schoenecker², Jason I. Ransom³ \\ Drew A. Ignizio ${ }^{4}$, and Tracy Mask ${ }^{1}$
}

\begin{abstract}
Aвstract.-The negative effects of equid grazers in semiarid ecosystems of the American West have been considered disproportionate to the influence of native ungulates in these systems because of equids' large body size, hoof shape, and short history on the landscape relative to native ungulates. Tools that can analyze the degree of influence of various ungulate herbivores in an ecosystem and separate effects of ungulates from effects of other variables (climate, anthropomorphic disturbances) can be useful to managers in determining the location of nonnative herbivore impacts and assessing the effect of management actions targeted at different ungulate populations. We used remotely sensed data to determine the influence of native and nonnative ungulates and climate on vegetation productivity at wildlife refuges in Oregon and Nevada. Our findings indicate that ungulate biomass density, particularly equid biomass density, and precipitation in winter and spring had the greatest influence on normalized difference vegetation index (NDVI) values. Our results concur with those of other researchers, who found that drought exacerbated the impacts of ungulate herbivores in arid systems.
\end{abstract}

RESUMEn.-Los efectos negativos de los equinos herbívoros en ecosistemas semi-áridos del oeste americano han sido considerados desproporcionados en comparación con la influencia de los ungulados nativos de estos sistemas por causa de su gran tamaño corporal, la forma de sus pezuñas y corta historia en el paisaje en relación con los ungulados nativos. Las herramientas que pueden analizar el grado de influencia de varios herbívoros ungulados en un ecosistema y separar esos efectos de aquellos causados por otras variables (clima, perturbaciones antropomórficas) pueden ser útiles para que los encargados puedan determinar la localidades de impacto por los herbívoros no nativos y para que evalúen el efecto de las acciones de manejo dirigidas a diferentes poblaciones de ungulados. Utilizamos datos de sensores remotos para determinar la influencia de los ungulados nativos y no nativos y del clima en la productividad de la vegetación en los refugios de vida silvestre de Oregon y Nevada. Nuestros hallazgos indican que la densidad de biomasa de ungulados, particularmente la densidad de biomasa de equinos, y las precipitaciones de invierno y primavera tenían la mayor influencia sobre los valores del índice normalizado de diferencia de vegetación (INDV). Nuestros resultados concuerdan con los de otros investigadores que descubrieron que la sequía exacerbó los impactos de los ungulados herbívoros en sistemas áridos.

Any use of trade, product, or firm names is for descriptive purposes only and does not imply endorsement by the U.S. Government.

Herbivory has profound effects on vegetation production, composition, and structure in many different plant communities (Hobbs 1996, Wisdom et al. 2006). Herbivores directly (Knapp et al. 1999) and indirectly influence ecosystem processes in plant structure and function and in both aboveground and belowground processes (Schoenecker et al. 2004, Bardgett and Wardle 2010). The influence of herbivory on ecosystem processes is shaped by the types of plants consumed, intensity of herbivory, evolutionary history of grazing, and availability of water and nutrients to plants (Milchunas and Lauenroth 1993). Herbivory by native and nonnative ungulates can exert impacts on vegetation production that stimulate compensatory plant production ("grazing optimization") at one end of the spectrum or suppress vegetation production ("undercompensation") at the other (McNaughton 1983, Maschinski and Whitham 1989). Evaluating the response of vegetation is one method to

\footnotetext{
${ }^{1}$ U.S. Geological Survey, Fort Collins Science Center, 2150 Centre Avenue, Bldg. C, Fort Collins, CO 80526.

${ }^{2}$ U.S. Geological Survey, Fort Collins Science Center, and Department of Ecosystem Science and Sustainability, Colorado State University, 2150 Centre Avenue, Bldg. C, Fort Collins, CO 80526.

${ }^{3}$ National Park Service, and Department of Ecosystem Science and Sustainability, Colorado State University, 1201 Oakridge Dr., Suite 200, Fort Collins, CO 80525 .

${ }^{4}$ Cherokee Services Group, Contracted to U.S. Geological Survey, Fort Collins Science Center, 2150 Centre Avenue, Bldg. C, Fort Collins, CO 80526

5Present address: 142 Salmon Lane, Carson,WA 98610. E-mail: linda_zeigenfuss@usgs.gov
} 
investigate the importance of abiotic inputs and disturbances on a system and to determine if ungulate herbivores exert significant impacts.

The effect of horse grazing on semiarid ecosystems has been widely documented (Hanley and Hanley 1982, Beever et al. 2003, 2008, Beever and Herrick 2006, Catorci et al. 2012). Presence of horses increases soil compaction, increases soil penetration resistance (particularly in drier soils; Beever et al. 2008), leads to soil nutrient depletion (due to reduction of vegetation cover), and increases soil erosion (Beever and Herrick 2006). Horse grazing promotes plants with low nutrient requirements and robust defense strategies (Catorci et al. 2012). However, the impacts of grazing by horses on arid environments are highly influenced by animal density and abiotic factors (Ostermann-Kelm et al. 2009). Whereas biogeography and abiotic factors may show a greater influence than horse grazing on variables such as percentage of vegetation cover and cover of key plant species (often highly palatable grasses; Fahnestock and Detling 1999, Beever et al. 2003), numerous studies have reported impacts of horse grazing on nesting bird communities (Zalba and Cozzani 2004), reptile species richness and abundance (Beever and Brussard 2004), nonnative plant cover (Loydi and Zalba 2009), and disturbancesensitive variables, such as soil surface hardness and number of ant mounds (Beever et al. 2003).

Managing free-roaming ${ }^{1}$ horse (Equus caballus) and burro (Equus asinus) herds and their habitats is an ongoing challenge for public land managers due to high reproduction and survivorship of horses and burros, diverse landcover and land-use conditions, and regulatory constraints on management options (National Academy of Sciences 2013). Free-roaming horse populations may increase at rates exceeding $20 \%$ annually (Eberhardt et al. 1982, Garrott et al. 1991) and have a wide array of influences on native flora, fauna, and ecosystem processes (Smith 1986, Levin et al. 2002, Beever and Brussard 2004, Zalba and Cozzani 2004, Beever and Herrick 2006, Beever et al. 2008, Loydi and Zalba 2009). Herds can range across management and political boundaries and compete with native wildlife and domestic livestock for forage. Therefore, understanding the relationship between herd management and habitat condition is an important need for managers across rangelands of the western United States.

The Sheldon National Wildlife Refuge (NWR) and Hart Mountain National Antelope Refuge (NAR) were established in 1931 and 1936, respectively, for conservation of high desert habitat for pronghorn (Antilocapra americana) and other sagebrush-obligate species. Together, the refuges comprise over $\sim 323,750$ ha $(800,000$ acres) of sagebrushsteppe ecosystem. Feral horses and burros have been present on Sheldon NWR since before the refuge was established. Burros became feral when domestic animals were released into the wild after the decline of mining and the advent of railroad and motorized vehicles in the American West (McKnight 1958, Douglas and Leslie 1996). Similarly, horses became feral as animals escaped or were released from ranches and grazing allotments. Recently, these refuges have experienced expanding utilization by feral horses and burros, leading to wildlife and habitat management challenges. Sheldon NWR hosted a feral horse population ranging from 200-300 horses in the mid 1990s to an estimated 973 horses by 2012. The burro population is generally small, with $\sim 200$ burros on the refuge in 2012. Hart Mountain NAR, which removed all horses from the refuge in the mid-1990s, now only occasionally contains a small number of animals that move onto the refuge from adjacent BLM lands (no horses from 1999 to 2005 and an average of 117 horses from 2006 to 2012), requiring periodic removal to maintain the refuge as horse-free. Hart Mountain NAR eliminated all domestic livestock grazing in 1990, and Sheldon NWR removed most livestock in 1990 and became completely livestockfree in 1994.

Animals (in this case, grazing animals) can influence the ecological health of natural systems. Analyzing these animal-ecosystem relationships to determine specific effects can provide support and direction for management actions. We analyzed the relationship of annual aboveground net primary productivity (ANPP) with ungulate populations and climate variables across the Sheldon-Hart Mountain

1The terms "free-roaming," "free-ranging," "feral," and "wild" are used interchangeably by horse and burro management agencies and in scientific literature, and refer to horses and burros that live in an untamed state but have ancestors that were once domesticated. In this paper, we refer to the animals in general as free-roaming and those horses occupying Sheldon NWR as feral. 


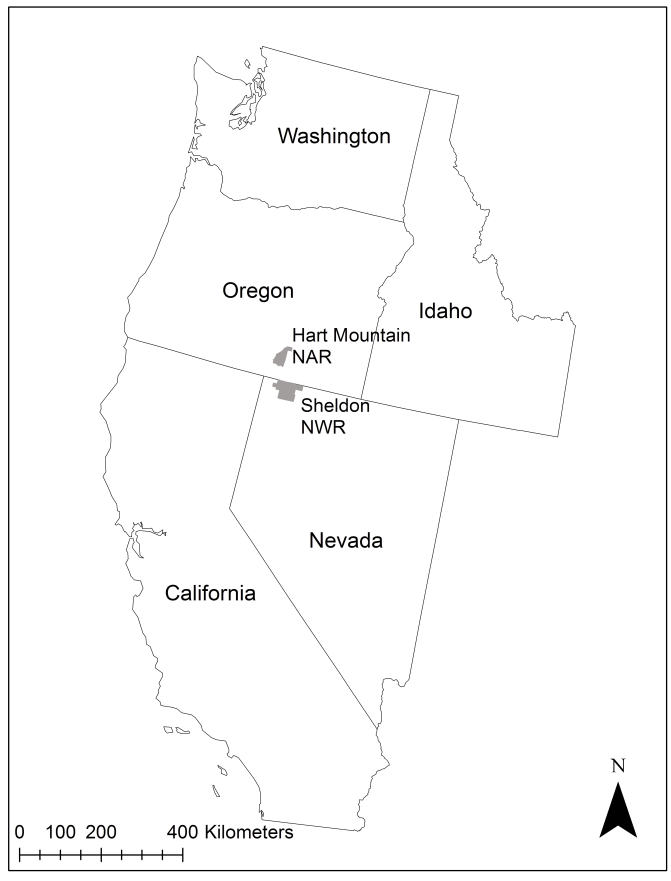

Fig. 1. Location of Sheldon-Hart Mountain National Wildlife Refuge Complex in the western United States.

National Wildlife Refuge Complex. We assessed the impact of ungulate density on temporal and spatial patterns in ANPP at the landscape scale by using a novel approach that accounts for ungulate body mass as well as population size. Our objective was to provide managers with a more comprehensive ecological understanding of the system and a better understanding of the potential impacts and habitat interactions of feral equids.

\section{METHODS}

\section{Study Area}

The Sheldon-Hart Mountain National Wildlife Refuge Complex (Fig. 1) is located in the Great Basin Ecosystem, which encompasses a portion of the Columbia Basin Plateau in eastern Oregon and southern Idaho, as well as the Great Basin Region, which extends from the Sierra Nevada in eastern California, across most of Nevada north of the Mojave Desert, to the Rocky Mountains in western Utah (Suring et al. 2005, USDI 2012). Lower-elevation portions of this ecosystem are defined by sagebrush (Artemisia spp.) steppe, salt desert shrub, and pinyon (Pinus monophylla) and juniper
(Juniperus spp.) woodland habitats. Both refuges are dominated by expansive communities of sagebrush steppe, which predominantly consists of sagebrush shrubs and an understory of native bunchgrasses and forbs.

The Hart Mountain NAR is 114,335 ha ( 282,500 acres) of high desert habitat located in south central Oregon. The refuge was established in 1936 as a range for remnant herds of pronghorn (Antilocapra americana). Hart Mountain NAR is located on a massive fault block ridge that ascends abruptly nearly threequarters of a mile above the Warner Valley floor in a series of rugged cliffs, steep slopes, and knife-like ridges (USDI 1994; www.fws.gov/ sheldonhartmtn/hart/index.html). The east side of the mountain is less precipitous, descending in a series of rolling hills and low ridges to the sagebrush-grasslands typical of the Great Basin region. Ungulate species include pronghorn, California bighorn sheep (Ovis canadensis californiana), mule deer (Odocoileus hemionus), and occasionally small numbers of trespass horses from adjacent BLM lands. Since 2007, a small group ( $\leq 11$ individuals) of elk (Cervus elaphus) has been observed occasionally during summer surveys. Elevations on the refuge range from 1350 to $2450 \mathrm{~m}(4450-8000 \mathrm{ft})$.

The Sheldon NWR is located in the northwestern corner of Nevada. This refuge was set aside in 1931 by executive order, primarily for the conservation of pronghorn and other native wildlife species. It protects 234,703 ha ( 580,000 acres) of high desert habitat for large summering herds of pronghorn, scattered bands of California bighorn sheep, mule deer, and feral horses and burros. The landscape is vast, rugged, and punctuated with waterfalls, narrow gorges, lush springs among rolling hills, and expansive tablelands of sagebrush and mountain mahogany (Cercocarpus montanus) (http://www.fws.gov/sheldonhartmtn/sheldon/ index.html). Elevations on the refuge range from 1250 to $2200 \mathrm{~m}(4100-7200 \mathrm{ft})$.

Mean annual precipitation is approximately $26 \mathrm{~cm}$ (10 in.) on both refuges but ranges from as little as $15 \mathrm{~cm}$ (6 in.) at lower elevations to $45 \mathrm{~cm}$ (18 in.) at high elevations, with roughly one-third falling as snow. Water resources are typical of the closed watersheds in the Great Basin. Streams, ponds, and playas within these watersheds are intermittent and typically dry during the summer months. Numerous wetlands and springs, as well as developed water 
TABLE 1. Minimum population estimates for ungulate species at Hart Mountain (Hart) and Sheldon (Shdn) National Wildlife Refuges, 2000-2012. These data were used to calculate ungulate biomass density for parameters/dependent variables in the model. Census data were provided by G. Collins of the U.S. Fish and Wildlife Service. Estimates are provided for mule deer and for Sheldon NWR bighorn (italics). Missing data points (bold type) were estimated by calculating midpoints between census dates (Sheldon) or applying local horse population growth rates of $17.5 \%$ (Hart). Missing data points shaded gray were estimated based on available census estimates and numbers of animals removed in years with missing data points. Horse and burro removals took place in years marked with an asterisk (*).

\begin{tabular}{|c|c|c|c|c|c|c|c|c|c|c|}
\hline \multirow[b]{2}{*}{ Year } & \multicolumn{2}{|c|}{ Horses } & \multicolumn{2}{|c|}{ Burros } & \multicolumn{2}{|c|}{ Pronghorn } & \multicolumn{2}{|c|}{ Bighorn } & \multicolumn{2}{|c|}{ Mule Deer } \\
\hline & Hart & Shdn & Hart & Shdn & Hart & Shdn & Hart & Shdn & Hart & Shdn \\
\hline 2000 & 0 & $628 *$ & 0 & 31 & 1759 & 1190 & 235 & 150 & 200 & 200 \\
\hline 2001 & 0 & 654 & 0 & 37 & 1617 & 1193 & 240 & 150 & 200 & 200 \\
\hline 2002 & 0 & $847 *$ & 0 & $97 *$ & 1905 & 1112 & 198 & 150 & 200 & 200 \\
\hline 2003 & 0 & 867 & 0 & $136^{*}$ & 2444 & 1031 & 305 & 150 & 200 & 200 \\
\hline 2004 & 0 & 1178 & 0 & $74^{*}$ & 2474 & 1404 & 301 & 150 & 200 & 200 \\
\hline 2005 & 0 & $1296^{*}$ & 0 & $68 *$ & 2372 & 1777 & 286 & 150 & 200 & 200 \\
\hline 2006 & 147 & $1065^{*}$ & 0 & 75 & 2716 & 2150 & 229 & 150 & 200 & 200 \\
\hline 2007 & 218 & 786 & 0 & 88 & 2052 & 1091 & 230 & 150 & 200 & 200 \\
\hline 2008 & 101 & $1148^{*}$ & 0 & 161 & 2024 & 1883 & 212 & 150 & 200 & 200 \\
\hline 2009 & $270^{*}$ & $1210^{*}$ & 0 & $127 *$ & 1942 & 1836 & 147 & 150 & 200 & 200 \\
\hline 2010 & 22 & $1225^{*}$ & 0 & $94^{*}$ & 2203 & 1727 & 130 & 150 & 200 & 200 \\
\hline 2011 & 31 & $1104^{*}$ & 0 & 138 & 1795 & 1974 & 134 & 150 & 200 & 200 \\
\hline 2012 & 28 & $973^{*}$ & 0 & 182 & 3723 & 2508 & 147 & 150 & 200 & 200 \\
\hline
\end{tabular}

resources (reservoirs, stock ponds, guzzlers, and pit reservoirs), are found throughout the study area. Water supply is dependent on the accumulation of winter snowpack. Snowpack depth and persistence into the early summer determine how much water will accumulate in playas and reservoirs and how much will flow through the creeks (USDI 1994, 2012).

Both refuges have a history of livestock grazing of both sheep (Ovis aries) and cattle (Bos taurus). Signs of excessive grazing (vegetation cover depletion, topsoil erosion) were noted at both refuges in the 1920s and 1930s (USDI 1994, 2012). Grazing decreased in the 1930s due to the Great Depression, and all domestic sheep grazing was eliminated from Sheldon in the 1950s and Hart Mountain by 1960. From 1940 to 1976, approximately 20,000 animal unit months (AUMs) of domestic horse, cattle, and sheep grazing occurred on Sheldon (USDI 2012), dropping to approximately 17,721 AUMs of cattle in the 1980s (Anderson and Franzen 1978). Most cattle grazing was seasonal from April through October. At Hart Mountain, seasonal livestock grazing ranged from 10,406 to 17,228 AUMs (USDI 1994). All livestock grazing ceased in 1990 on Hart Mountain and by 1994 on Sheldon.

\section{Ungulate Population Density}

We obtained minimum population estimates of all large grazing species present on Sheldon NWR and Hart Mountain NAR from the U.S.
Fish and Wildlife Service (Table 1; G. Collins, USFWS, personal communication, April 2013). The same suite of ungulate herbivores (pronghorn, bighorn sheep, mule deer, horses, and burros) was present in both areas during the study period, with the exception of burros, which have never been present at Hart Mountain NAR, and a few elk $(\leq 11)$ that have been observed there periodically during summer over the past 5 years. Horses, burros, and bighorns occupy the refuges year-round. Typically, pronghorn and mule deer are on the refuges April through October. A portion of the pronghorn population is resident year-round in years with mild winters, but pronghorn leave the refuges in average or harsh winters. The majority of mule deer migrate off the refuges in winter, but a small group does reside in a sheltered valley at Sheldon NWR through the winter. Annual minimum population counts were conducted in July for California bighorn sheep at Hart Mountain, pronghorn at both refuges, horses at both refuges, and burros at Sheldon. For years when population data were not available, population size estimates were made by assessing the change in population over the time period between data points and assigning population numbers to missing years that assumed a steady rate of increase or decrease between the 2 data points. At Hart Mountain all horses were removed by 1999 , but sometime in 2005-2006, a herd gained access to the refuge and increased until it was 
removed in 2009. Small numbers of trespass horses used the refuge between 2009 and 2012.

Using these ungulate population data for each year and refuge, we estimated total ungulate biomass density (UBD) using the following equation:

$$
U B D=\frac{\sum_{i=1}^{n}\left(P_{i} \times w t_{i} \times s_{i}\right)}{a},
$$

where $i=$ an individual species, $P_{i}=$ refuge population size for species $i, w t_{i}=$ average body mass $(\mathrm{kg})$ for species $i$ (Table 2$), s_{i}=$ seasonality factor (the proportion of the year that species $i$ is on the refuge; Table 2), and $a=$ area (ha) of the refuge. We included a seasonality factor to account for migration of animals off the refuges during winter. Only pronghorn and mule deer were regularly migratory, and patterns were highly variable depending on winter severity. Therefore, for these 2 species, we assumed that in most years the majority of the population was only resident from April through October (0.58 year). We partitioned ungulate biomass density into equid (horse and burro) and nonequid (all other ungulates) components for statistical analysis. Because the number of elk was so small and elk were only occasionally observed (G. Collins, U.S. Fish and Wildlife Service, personal communication), ungulate biomass density estimates did not include elk.

\section{Vegetation Productivity}

We conducted refuge-scale assessments of aboveground net primary production (ANPP) throughout the year by using remotely sensed satellite images from the Moderate Resolution Imaging Spectroradiometer (MODIS) platform. We used the normalized difference vegetation index (NDVI), which is particularly wellsuited for this application because it can be used for characterizing land surface biophysical properties and processes, such as primary production (https://lpdaac.usgs.gov/products/ modis_products table/mod $13 q 1)$. NDVI is a well-established index used to identify the "level of greenness" of a landscape. This greenness is measured using satellite-based sensors that measure the intensity of light being reflected off the Earth in visible and near-infrared wavelengths to quantify the photosynthetic capacity of vegetation in a given area of land surface. Several sources of NDVI imagery exist, but we selected MODIS because of its higher spatial resolution (250-m resolution) and greater temporal resolution (16-day interval) compared to other available sources. The MODIS platform was launched in 1999, and the first year of complete MODIS data for the SheldonHart region is 2000. Our analysis covers the period from 2000 to 2012. Data were downloaded from the MODIS website for the years 2000 to 2012 (http://earthexplorer.usgs.gov/). The data used represent the MODIS $250 \mathrm{~m}$ resolution, 16-day interval vegetation products.

After we downloaded the tiles, we extracted data using the Geospatial Data Abstraction Library (GDAL) utility in conjunction with Python code. Raster data sets were assigned proper spatial reference, rescaled (raster values were multiplied by 0.0001 to adjust NDVI values, as they had been modified to address file size limitations), and reprojected into a WGS 84 Sinusoidal Projection. This projection was chosen to limit data loss by preserving a projection as similar to the native format as possible but also to transform the data into a more commonly used datum to facilitate proper processing. Finally, we mosaicked the raster data sets to produce single raster files representing NDVI readings for a large multistate region covering the area of interest (AOI) for each date of imagery capture.

We used individual polygons representing the 2 refuge areas to calculate zonal statistics using the ESRI ArcGIS desktop software package (ESRI 2010). For each refuge, we considered all of the raster cells from the NDVI data set that fell within the spatial extent of the refuge, and descriptive statistics (mean, minimum, maximum, range, and standard deviation of the values within the polygon) were then calculated. These values were captured and saved into formatted tables for every 16-day time step throughout each year for all years between 2000 and 2012. We then averaged over all sample dates within the growing season for each year to get an average growing season NDVI for each refuge. Maximum growing season NDVI scores were taken from the date within each year that had the highest NDVI score for each refuge polygon.

We estimated vegetation phenology metrics (green-up date, browndown date, and date of peak greenness) for each year at both refuges from the MODIS data, following algorithms described by Tan et al. (2011). For the years 
2000 and 2008-2012, MODIS coverage of the study area was poor for several dates, causing the Tan et al. (2011) algorithm to perform poorly when estimating green-up and browndown dates. For these years, we estimated green-up and browndown date by fitting a 3period moving-average trendline (MSExcel) to the mean vegetation index values for each study area throughout the year. We then visually inspected the graph for the sampling date at which vegetation index values began to increase steadily (green-up), the date of the maximum index value (peak value), and the date when the vegetation index ceased to decrease steadily (browndown).

\section{Climate Variables}

We obtained climate data for both refuges from 1999 to 2012. We gathered precipitation and temperature data for Hart Mountain NAR from the Rock Creek weather station (\#GHCND:USR0000OROC; National Climatic Data Center, http://www.ncdc.noaa.gov). We obtained climate data for Sheldon NWR from the Sheldon SNOTEL site (\#NV19H05S; Natural Resources Conservation Service, http:// www.wcc.nrcs.usda.gov/snow/snotel-precipdata.html).

\section{Statistical Analysis}

We combined data from Sheldon NWR (large horse population) and Hart Mountain NAR (few horses, more pronghorn) over 13 years to determine the relative impact of freeroaming equid population densities on vegetation productivity measured by NDVI $(n=26)$. Due to the scale of the sensor (ground resolution: $250 \times 250 \mathrm{~m}$ cell), this assessment did not provide fine-scale indication of range conditions as would be provided by field assessment. But this resolution, combined with the frequent temporal interval of a new composite image every 16-32 days, provided the spatial and temporal resolution needed to assess patterns and impacts across the entire refuge complex.

We formulated a set of candidate statistical models that were based on likely ecological relationships by using additive formulations of the following variables: (1) estimated ungulate biomass density (total, equid, and nonequid); (2) precipitation metrics including total precipitation during growth period (from green-up to peak of growing season [date of maximum greenness index value]), total growing season precipitation (from current year green-up to browndown), and total winterspring precipitation (from previous year browndown to peak greenness); and (3) temperature metrics, including mean daily temperature and mean maximum daily temperature during the growth period, winter-spring temperature, and full-growing-season temperature. Growing season commencement and duration are tied to climatic conditions, which vary from year to year. Because we had information available on green-up and peak greenness from the NDVI data, we decided to use this information to tailor the precipitation and temperature data more precisely for each year, rather than use standardized dates across years to calculate these variables. The resulting list of candidate models had a maximum of 6 variables for maximum growing-season NDVI and 8 variables for average growing-season NDVI. Maximum index values were only tested with growth period and winter-spring climate data, since temperature and rainfall occurring after the peak of the growing season would not have the opportunity to affect this value.

We conducted all statistical analyses using SAS version 9.2 (SAS Institute, Cary, NC). We first tested for differences in slopes of parameters for each refuge to determine if models needed to be compared separately for each refuge using PROC GLM in SAS. Model selection was based on adjusted $\mathrm{R}^{2}$, and strength of evidence for models was evaluated using Akaike's information criteria for small sample sizes ( $\mathrm{AIC}_{c}$; Burnham and Anderson 2002).

We tested all variables (precipitation, temperature, ungulate biomass density) for correlations, and when significant correlation between 2 variables was found, we excluded models with correlated variables from consideration.

We compared the absolute values of $t$ statistics for each parameter of the model to provide a measure of the relative importance of predictor variables (Bring 1994). For each model, we identified the variable with the highest $t$ value as being the most important, and then determined the relative importance of all other variables in relation to the most important using a ratio of their $t$ statistics.

\section{Caveats and Limitations}

The parameters that were used to examine relationships represent available data, but in 


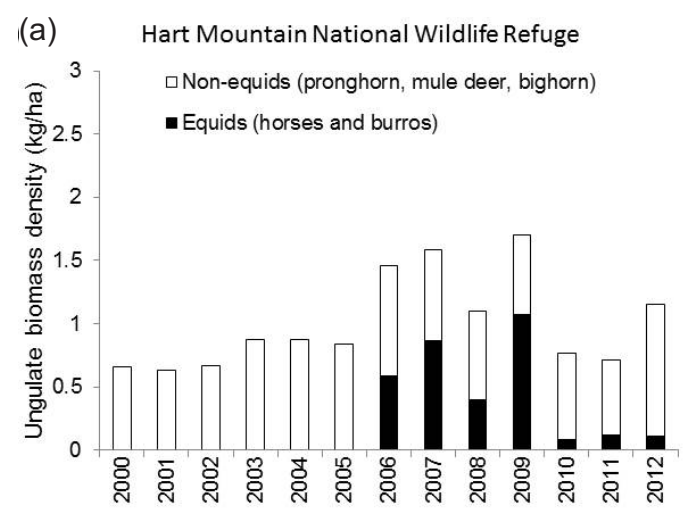

(b)

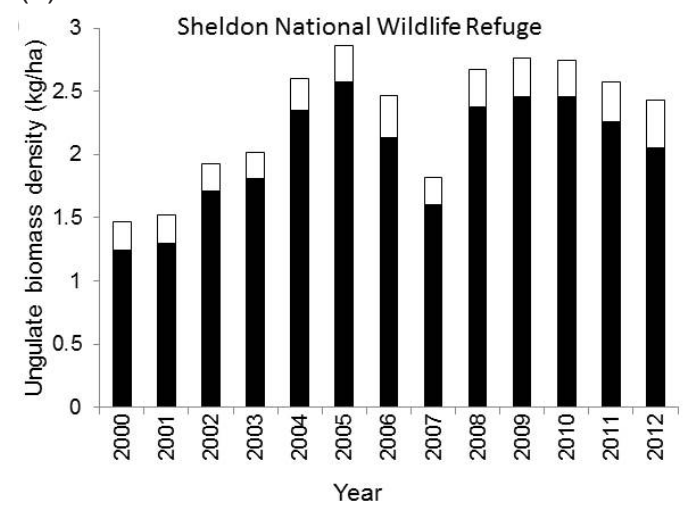

Fig. 2. Annual equid and non-equid ungulate biomass densities at (a) Hart Mountain and (b) Sheldon National Wildlife Refuges, 2000-2012.

many cases the parameters are generalized approximations of actual field conditions or are limited by methods used to collect data. Satellite imagery is subject to problems related to cloud cover at the time of sampling and shading effects. These issues, in turn, affect NDVI values derived from these scenes. Population data were gathered once per year from surveys of the entire study area, and no corrections to account for sampling error were made. In years when population surveys were not conducted, estimates of population size (based on surveyed population size for the years previous to and following the missing years) were used. The study areas have varied topography and microhabitats, and we simplified NDVI to represent the entire study area with a single value. This landscape has been heavily influenced by historic livestock grazing, and residual effects of decades of livestock grazing at high intensities may continue to
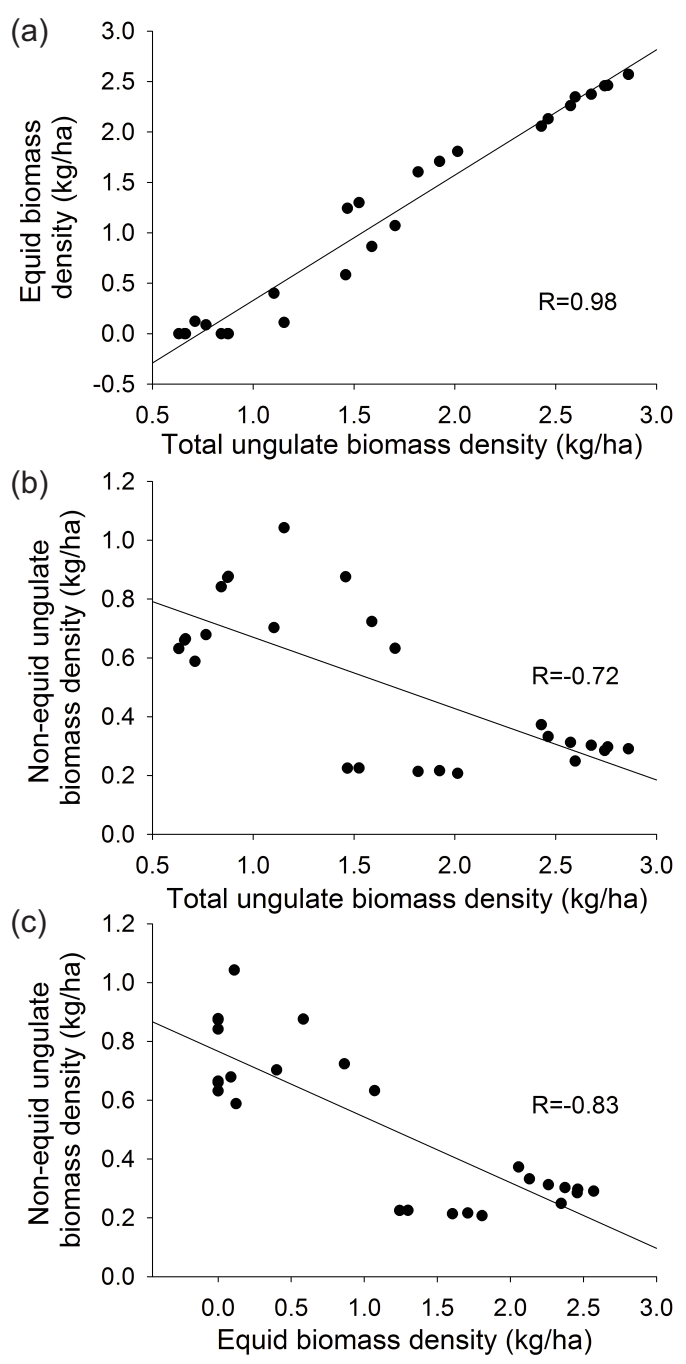

Fig. 3. Correlations of (a) equid and (b) non-equid ungulate biomass density with total ungulate biomass density and (c) with each other at the Sheldon and Hart Mountain National Wildlife Refuge Complex, 2000-2012.

influence this landscape but would not be detected by our study. Our objective was to find general patterns in the data under the current conditions at the scale of the refuge, and these patterns are not necessarily applicable to individual vegetation types or other smaller habitat/vegetation units.

\section{RESUlTS}

Estimates for ungulate populations at both locations varied greatly from 2000 to 2012 (Table 1). The following factors contributed to 
TABLE 2. Average body mass constants used to calculate ungulate biomass density. Data for seasonality factor was provided by G. Collins, U.S. Fish and Wildlife Service, Sheldon-Hart Mountain National Wildlife Refuge Complex.

\begin{tabular}{lclc}
\hline Ungulate species & Average body mass $(\mathrm{kg})$ & Grazing season & Seasonality factor \\
\hline Horse $^{\mathrm{a}}$ & 454 & Year-round & 1.00 \\
Burro $^{\mathrm{a}}$ & 227 & Year-round & 1.00 \\
Pronghorn $^{\mathrm{b}}$ & 45 & April-October & 0.58 \\
Bighornb $^{\mathrm{b}}$ & 91 & Year-round & 1.00 \\
Mule deerb $^{\mathrm{b}}$ & 68 & April-October & 0.58
\end{tabular}

abody mass value obtained from the U.S. Bureau of Land Management Wild Horse and Burro Program (http://www.blm.gov/or/resources/whb/files/adoption_ requirements.pdf)

body mass value obtained from Wassink (1993).

annual population fluctuations: removal of horses and burros from both populations throughout the study period (Table 1), unquantified errors in population estimation, occasional movement of horses and burros from adjacent lands in both populations, and increased use of water sources on the refuge complex by pronghorn during drought years (G. Collins, USFWS, personal communication).

Throughout the study period, total and equid ungulate biomass density were greater at Sheldon than at Hart Mountain, with the exception of 2007 (Fig. 2), which followed large decreases in horse (due to removals) and pronghorn populations at Sheldon. Throughout the study, Hart Mountain had greater nonequid biomass density than Sheldon (Fig. 2). All biomass density variables were correlated. Total ungulate biomass density was highly correlated with equid biomass density $(\mathrm{R}=0.98, P<0.0001$; Fig. 3a). Equids, due to their large body size, drove the total ungulate biomass density in these study areas, despite their lower population size compared to pronghorn (Table 2). In addition, total ungulate biomass density was negatively correlated with non-equid biomass density $(\mathrm{R}=$ $-0.72, P<0.0001$; Fig. $3 \mathrm{~b}$ ). We found a strong negative correlation between equid and nonequid biomass density $(\mathrm{R}=-0.83, P<$ 0.0001; Fig. 3c). However, we did not test for, and our results do not necessarily demonstrate, a causal relationship (i.e. high equid biomass density is leading to lower non-equid biomass density), because equid populations are controlled in these areas and because man-made water sources on the refuges may influence both equid and non-equid population size in any given year. We tested all 3 ungulate biomass density variables to see which had the greatest effect on NDVI, but because of correlations, we did not consider models that had more than one of these variables.

Similarly, all precipitation variables were highly correlated with each other $(\mathrm{R} \geq 0.85, P$ $<0.0001)$ so no model that included more than one precipitation variable was considered. This high correlation is not surprising because the selected periods for precipitation overlapped. Mean temperatures during all periods evaluated (winter-spring, growing season, and growth period) were positively correlated with mean maximum temperatures during the same period $(\mathrm{R} \geq 0.71, P<0.0001)$. As with precipitation, temperature variables were also correlated across time periods, so no models with more than one temperature variable were included in the set of candidate models.

The top-ranked models for both average growing-season NDVI and maximum growingseason NDVI included equid biomass density or total ungulate biomass density and total winter-spring precipitation (Table 3). Although the model for predicting maximum growingseason NDVI was significant $(P=0.009)$, the modeled relationship was not strong $\left(\mathrm{R}^{2}=\right.$ $0.34)$. Increases in equid biomass negatively influenced NDVI, whereas increases in winterspring precipitation positively influenced NDVI (Fig. 4). Relationships of average growingseason NDVI to predictor variables were much stronger $\left(\mathrm{R}^{2}\right.$ ranged from 0.63 to 0.66$)$ than those for maximum growing-season NDVI $\left(\mathrm{R}^{2}=0.24-0.34\right)$.

A comparison of $t$ statistics provided a measure of the relative importance of each model variable (Bring 1994). We found that biomass density (both equid and total ungulate) had greater importance than total winter-spring precipitation for average growing-season NDVI (Table 3). However, winter-spring precipitation was slightly more important than biomass density in predicting maximum growingseason NDVI (Table 3). 
TABLE 3. Top-ranked models (based on $\mathrm{AIC}_{c}$ score) that best predicted vegetation indices of greenness at the SheldonHart Mountain National Wildlife Refuge Complex. All models within $2 \mathrm{AIC}_{c}$ points of the highest-ranking model are included.

\begin{tabular}{|c|c|c|c|c|c|c|c|c|}
\hline Response & $\mathrm{R}^{2}$ & Model $P$ & $\mathrm{AIC}_{c}$ & Independent variables & $P$ & $\beta$ & $t$ & Importance \\
\hline \multirow{10}{*}{ Mean NDVI } & \multirow[t]{3}{*}{0.65} & \multirow{3}{*}{$<0.001$} & \multirow[t]{3}{*}{-212.2} & Equid biomass density & $<0.001$ & -0.016 & -4.82 & 1 \\
\hline & & & & Winter-spring precipitation & 0.001 & 0.002 & 3.84 & 0.87 \\
\hline & & & & Intercept & $<0.001$ & 0.231 & 20.11 & - \\
\hline & \multirow[t]{3}{*}{0.63} & \multirow[t]{3}{*}{$<0.001$} & \multirow[t]{3}{*}{-210.2} & Ungulate biomass density & $<0.001$ & -0.019 & -4.46 & 1 \\
\hline & & & & Winter-spring precipitation & 0.001 & 0.002 & 3.90 & 0.87 \\
\hline & & & & Intercept & $<0.001$ & 0.242 & 18.14 & - \\
\hline & \multirow[t]{4}{*}{0.66} & \multirow[t]{4}{*}{$<0.001$} & \multirow[t]{4}{*}{-210.1} & Equid biomass density & $<0.001$ & -0.016 & -4.67 & 1 \\
\hline & & & & Winter-spring precipitation & 0.002 & 0.002 & 3.62 & 0.78 \\
\hline & & & & Winter-spring max temp & 0.510 & -0.001 & -0.67 & 0.14 \\
\hline & & & & Intercept & $<0.001$ & 0.247 & 9.38 & - \\
\hline \multirow[t]{15}{*}{ Max NDVI } & \multirow[t]{3}{*}{0.34} & \multirow[t]{3}{*}{0.009} & \multirow[t]{3}{*}{-164.4} & Ungulate biomass density & 0.040 & -0.022 & -2.18 & 0.91 \\
\hline & & & & Winter-spring precipitation & 0.025 & 0.003 & 2.40 & 1 \\
\hline & & & & Intercept & $<0.001$ & 0.307 & 9.53 & - \\
\hline & \multirow[t]{3}{*}{0.33} & \multirow{3}{*}{0.010} & \multirow[t]{3}{*}{-164.3} & Equid biomass density & 0.042 & -0.017 & -2.15 & 0.93 \\
\hline & & & & Winter-spring precipitation & 0.030 & 0.003 & 2.31 & 1 \\
\hline & & & & Intercept & $<0.001$ & 0.029 & 10.15 & - \\
\hline & \multirow[t]{3}{*}{0.31} & \multirow{3}{*}{0.013} & \multirow[t]{3}{*}{-163.6} & Ungulate biomass density & 0.071 & -0.020 & -1.89 & 0.85 \\
\hline & & & & Growing period precipitation & 0.037 & 0.003 & 2.21 & 1 \\
\hline & & & & Intercept & $<0.001$ & 0.329 & 12.48 & - \\
\hline & \multirow[t]{3}{*}{0.31} & \multirow[t]{3}{*}{0.015} & \multirow[t]{3}{*}{-163.3} & Equid biomass density & 0.084 & -0.015 & -1.81 & 0.88 \\
\hline & & & & Growing period precipitation & 0.051 & 0.003 & 2.06 & 1 \\
\hline & & & & Intercept & $<0.001$ & 0.315 & 14.51 & - \\
\hline & \multirow[t]{3}{*}{0.24} & \multirow[t]{3}{*}{0.016} & \multirow[t]{3}{*}{-163.1} & Winter-spring temperature & 0.079 & 0.012 & 1.84 & 0.82 \\
\hline & & & & Winter-spring precipitation & 0.035 & 0.002 & 2.25 & 1 \\
\hline & & & & Intercept & $<0.001$ & 0.230 & 7.06 & - \\
\hline
\end{tabular}

\section{Discussion}

Different species of ungulates can influence plant communities in different ways. Largebodied grazers and browsers have a higher demand for forage; thus even small populations of such species can exert an influence on their habitat that is proportionately greater than the effect of a larger population of smaller, lighter ungulate herbivores. The data from Sheldon and Hart Mountain refuges appear to illustrate this point. At population levels represented in our study, equid biomass density had a negative effect on greenness (i.e., ANPP). The effect of ungulate herbivory became more pronounced over the length of an entire growing season. Equid biomass density was more important than winter-spring precipitation in models of average growing-season NDVI. This result likely indicates that herbivory is a greater determinant of how much productivity is sustained on the landscape during the growing season, regardless of the favorability of growing conditions. However, the relative importance of equid density in our model of maximum NDVI (i.e., maximum ANPP) was slightly lower, indicating that precipitation has the greatest influence in determining peak production.
This landscape has a history of heavy grazing. Prior to the elimination of domestic livestock grazing in the early 1990s, biomass density attributable to cattle grazing was 2-4 times greater $\left(3.4-5.6 \mathrm{~kg} \cdot \mathrm{ha}^{-1} \mathrm{y}^{-1}\right)$ at Hart Mountain than the current maximum ungulate biomass density. At Sheldon, cattle biomass density was roughly equivalent $\left(3.0 \mathrm{~kg} \cdot \mathrm{ha}^{-1} \mathrm{y}^{-1}\right)$ to current ungulate biomass density (equids, bighorn sheep, mule deer, and pronghorn). However, for many of the years when cattle were present, pronghorn and horse numbers were substantially lower than they are currently. In the case of Sheldon, increases in pronghorn and horse numbers following cessation of livestock grazing may have led to a much lower reduction in overall grazing pressure than anticipated, because horses are filling some of the void and they are on the refuge year-round. Vegetation communities at Sheldon have likely not had an extended rest and recovery period from grazing by populations of largebodied herbivores. At Hart Mountain, where previous livestock density was much greater and horse populations have been much lower, ungulate biomass density has dropped substantially and recovery of plant communities is much more likely. 
(a)

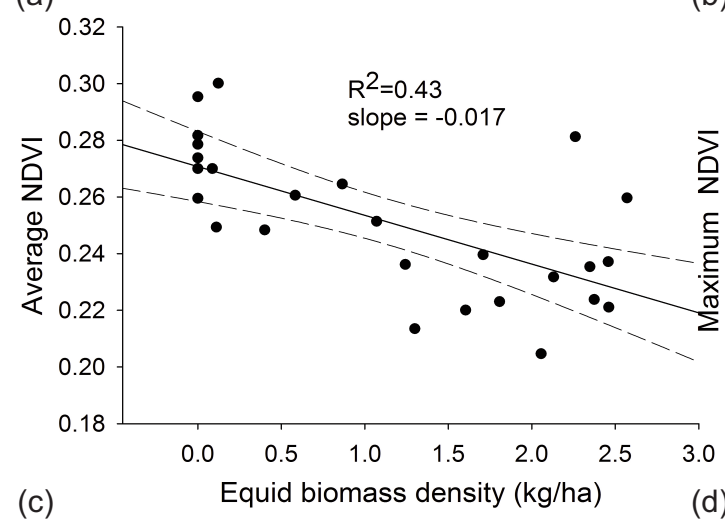

(b)

(d)
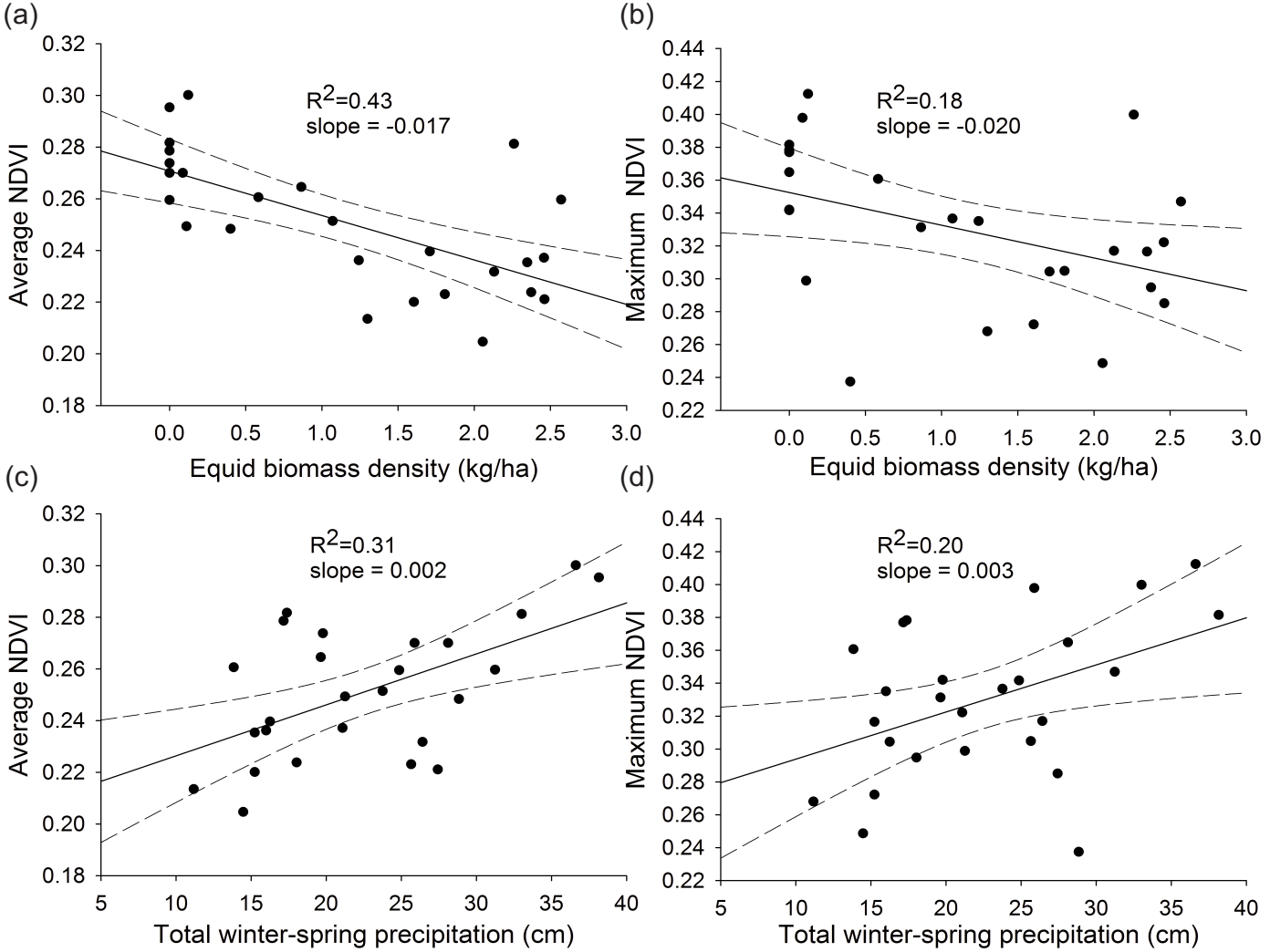

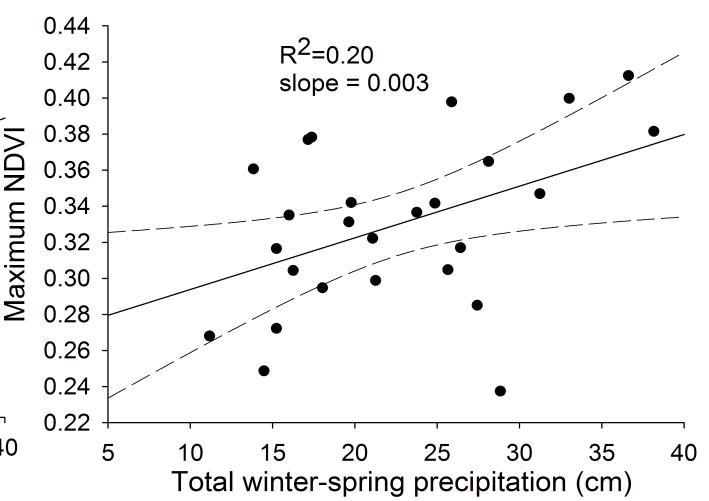

Fig. 4. Average and maximum NDVI were negatively influenced by increases in equid ungulate biomass density (a, b) but responded positively to increases in total winter-spring precipitation (c, d) at Sheldon and Hart Mountain National Wildlife Refuges. Dashed lines show 95\% confidence intervals around the regression lines.

Feral horses are the least selective ungulate herbivores in the western United States (Hanley and Hanley 1982, Beever 2003). In contrast to other ungulates present in this area, horses are cecal digesters. This characteristic, in combination with large body size, places more time-energy constraints on the animal, thus reducing selectivity (Beever 2003). Due to this low selectivity, fewer plant species may remain ungrazed in areas populated by feral horses (Beever 2003). Compared to rumination, cecal digestion also requires higher consumption of forage per kilogram of body mass. These factors may increase the likelihood that equids in particular have a greater impact on vegetation communities during drought years. Herbivory does have a greater impact on forage in dry years than in wet years (Fahnestock 1998), as grazing can exacerbate the effects of lower precipitation on ANPP. Other studies have reported an herbivore effect on growing season NDVI that was greater in dry years than in wet years and greater at arid sites than at wet sites (Blanco et al. 2008).

Vegetation indices, such as NDVI, use light reflectance from green vegetation to determine a "greenness" level of a portion of a landscape. Therefore, increases in the amount of green biomass in a landscape should result in increases in this index. Conversely, factors that cause senescence of green vegetation or that reduce the amount of green vegetation would be expected to contribute to decreases in NDVI. Precipitation is directly correlated with plant productivity in semiarid grassland ecosystems (Sala et al. 1988). Abundant moisture can lead to higher plant biomass production (greening), whereas lack of moisture may lead to early senescence (browndown) or plant death. NDVI is more tightly coupled with precipitation in drier ecosystems (Fabricante et al. 2009), and interannual variation of annual NDVI is 
also highly and widely correlated with precipitation accumulated during previous periods, depending on season and site (Fabricante et al. 2009). The relatively important rank of precipitation in our models for average and maximum NDVI during the growing season agrees with these findings. NDVI was lower, indicating lower ANPP, during years with low precipitation. Bradley and O'Sullivan (2011) observed no relationship between livestock grazing and NDVI at elevations above 2300 $m$ in south central Idaho, and they attributed this result to greater amounts of precipitation at higher elevations.

Other factors that may decrease landscape greenness are reduction of biomass through removal by grazing and plant mortality caused by overbrowsing of shrubs and trampling of herbaceous vegetation. Bradley and O'Sullivan (2011) modeled livestock (domestic sheep and cattle) grazing interactions with NDVI and observed that decreased NDVI was most likely in areas with livestock grazing, but the extent of impact differed depending on land use and elevation. The presence of horses reduces vegetation cover (Beever and Herrick 2006), which agrees with our model results of lower NDVI values (thus lower ANPP) in areas with equids. Although the use of remotely sensed greenness data is a useful tool in examining these long-term trends, these data may be limited when used in the absence of empirical information from the field. Bradley and O'Sullivan (2011) cautioned that low grazing levels may result in decreased NDVI if ungrazed grasses appear less green in subsequent years due to standing dry biomass. These authors acknowledge that NDVI changes in most locations are due to a change in percent cover of some combination of grasses, shrubs, and forbs, but they caution that the exact cause of these changes cannot be determined without field study.

Our results emphasize the importance of considering both biotic and abiotic factors when examining vegetation productivity. Management actions based only on the influence of climate variables on NDVI without consideration of the density, body mass, and foraging habitats of herbivores (or, conversely, actions aimed only at reducing herbivore numbers or distribution without regard to factors such as elevation, precipitation, and temperature) could result in continued or greater negative impacts of herbivory, particularly in arid systems. In scenarios of potential climate change, increased temperatures may not only drive plant greenness, but also ungulate use of the landscape (Allred et al. 2013, Beschta et al. 2013).

Anecdotal evidence from Hart Mountain suggests that pronghorn use increased on the refuge during drought years due to available water sources. How herbivores use the landscape relative to annual precipitation was not investigated in this study, but that relationship could well be an important factor in determining herbivore impacts on NDVI. Additionally, the timing of precipitation can be important. In tallgrass prairie, greater late-summer precipitation increased weight gain of large ungulates, but greater midsummer precipitation decreased ungulate weights (Craine et al. 2008). The decrease in weight gain with greater midsummer precipitation was associated with increased grass stem production, which is synonymous with lower forage quality. Although quantity of overall vegetation biomass increased, the quality of vegetation decreased, resulting in lower weight gains for ungulates (Craine et al. 2008). We used NDVI as a proxy for ANPP, a measurement of vegetation productivity; however, NDVI cannot be substituted for measures of vegetation quality, which can also greatly impact the dynamics of large herbivore-habitat interactions. Therefore, NDVI data alone may not be sufficient for management use if the goal is to determine the habitat quality that is sufficient for animal health and production.

In September 2012, following 4 years of public involvement and planning, the U.S. Fish and Wildlife Service approved its Comprehensive Conservation Plan (CCP) for managing Sheldon NWR (USDI 2012), including the decision to remove horses and burros from the refuge by 2017 . This decision was made in the interest of eliminating damage to habitats, including riparian areas; eliminating displacement of native wildlife and competition for forage and water resources; and removing risk to public safety by preventing collisions with vehicles on the highway through the refuge. It is difficult to predict the length of time to recovery of an ecosystem in response to horse removal. Several studies in western North America report no significant recovery of various ecosystem components even one to several decades after removal of the disturbing agent 
(McLean and Tisdale 1972, Rice and Westoby 1978, West et al. 1984, Heske and Campbell 1991, Knapp 1992). Other studies from the same region have found that ecosystems experiencing removal of grazing disturbance can exhibit significant changes over both short- and long-term time scales (Laycock 1967, Dormaar et al. 1994, Dobkin et al. 1998, Beever and Brussard 2000, Beever et al. 2003). Beever et al. (2008) found that removing horses from landscapes where they once roamed can result in a variety of vegetation changes, including increased shrub cover, greater total plant cover, greater plant species richness, and higher frequency of native grasses in as short as a decade. Resource managers also need to consider the effects of global climate change and management strategies for mitigation. Researchers suggest that reducing the impact of current stressors on landscapes is a management strategy that can facilitate adaptation to climate change on public lands in the western United States (Beschta et al. 2013).

\section{ACKNOWLEDGMENTS}

We gratefully acknowledge the assistance of Gail Collins, U.S. Fish and Wildlife Service, Sheldon-Hart Refuge Complex, in providing animal census data for both refuges and for answering numerous questions on grazing history and animal movements at both refuges. Sarah King, Natural Resources Ecology Lab at Colorado State University, provided helpful review comments. Brian Cade, U.S. Geological Survey, provided guidance on statistical matters. Funding for this work was provided through the U.S. Fish and Wildlife Service Science Support Partnership.

\section{Literature Cited}

Allred, B.W., S.D. Fuhlendorf, T.J. Hovick, R.D. Elmore, D.M. Engle, AND A. JoERn. 2013. Conservation implications of native and introduced ungulates in a changing climate. Global Change Biology 19:1875-1883

Anderson, E.W., and D. Franzen. 1978. Changes in ecological condition 1964-1978, Sheldon National Antelope Refuge, Nevada. U.S. Department of the Interior, U.S. Fish and Wildlife Service, Sheldon-Hart Mountain National Refuge Complex, Lakeview, OR.

Bardgett, R.D., AND D.A. WardLE. 2010. Abovegroundbelowground linkages; biotic interactions, ecosystem processes, and global change. Oxford University Press, Oxford. $301 \mathrm{pp}$.
BeEver, E. 2003. Management implications of freeroaming horses in semi-arid ecosystems of the western United States. Wildlife Society Bulletin 31(3):887-895.

Beever, E.A., And P.F. Brussard. 2000. Examining ecological consequences of feral horse grazing using exclosures. Western North American Naturalist 60: 236-254.

2004. Community- and landscape-level responses of reptiles and small mammals to feral-horse grazing in the Great Basin. Journal of Arid Environments $59: 271-297$.

Beever, E.A., AND J.E. Herrick. 2006. Effects of feral horses in Great Basin landscapes on soil and antsdirect and indirect mechanisms. Journal of Arid Environments 66:96-112.

Beever, E.A., R.J. Tausch, and P.F. Brussard. 2003. Characterizing grazing disturbance in semiarid ecosystems across broad scales, using diverse indices. Ecological Applications 13:119-136.

Beever, E.A., R.J. Tausch, and W.E. Thogmartin. 2008. Multi-scale responses of vegetation to removal of horse grazing from Great Basin (USA) mountain ranges. Plant Ecology 196:163-184.

Beschta, R.L., D.L. Donahue, D.A. DellaSala, J.J. Rhodes, J.R. Karr, M.H. O'Brien, T.L. Fleischner, AND C.D. WilLiams. 2013. Adapting to climate change on western public lands: addressing the ecological effects of domestic, wild, and feral ungulates. Environmental Management 51:474-491.

Blanco, L.J., M.O. Aguilera, J.M. Paruelo, and F.N. BiURrun. 2008. Grazing effect on NDVI across an aridity gradient in Argentina. Journal of Arid Environments 72:765-776.

Bradley, B.A., AND M.T. O’Sullivan. 2011. Assessing the short-term impacts of changing grazing regime at the landscape scale with remote sensing. International Journal of Remote Sensing 32:5797-5813.

BRING, J. 1994. How to standardize regression coefficients. American Statistician 48:209-218.

Burnham, K.P., and D.R. Anderson. 2002. Model selection and multimodel inference: a practical information-theoretic approach. 2nd edition. SpringerVerlag, New York, NY.

Catorci, A., R. Gatti, and S. Cesaretti. 2012. Effect of sheep and horse grazing on species and functional composition of sub-Mediterranean grasslands. Applied Vegetation Science 15:459-469.

Craine, J.M., E.G. Towne, A. Joern, and R.G. HamilTON. 2008. Consequences of climate variability for the performance of bison in tallgrass prairie. Global Change Biology 15:772-779.

Dobkin, D.S., A.C. Rich, AND W.H. Pyle. 1998. Habitat and avifaunal recovery from livestock grazing in a riparian meadow system of the northwestern Great Basin. Conservation Biology 12:209-221.

DormanR, J.F., B.W. Adams, and W.D. Willms. 1994. Effect of grazing and abandoned cultivation on a Stipa-Bouteloua community. Journal of Range Management 47:28-32.

Douglas, C.L., AND D.M. Leslie JR. 1996. Feral animals on rangelands. Pages 281-292 in P.R. Krausman, editor, Rangeland wildlife. Society for Range Management, Denver, CO.

Eberhardt, L.L., A.K. Majorowicz, and J.A. Wilcox. 1982. Apparent rates of increase for two feral horse herds. Journal of Wildlife Management 46:367-374. 
[ESRI] Environmental Systems Research Institute. 2010. ArcGIS desktop: release 10. ESRI, Redlands, CA.

Fabricante, I., M. Oesterheld, and J.M. Paruelo. 2009. Annual and seasonal variation of NDVI explained by current and previous precipitation across Northern Patagonia. Journal of Arid Environments 73:745-753.

FAHNESTOCK, J.T. 1998. Vegetation responses to herbivory and resource supplementation in the Pryor Mountain wild horse range. Doctoral dissertation, Colorado State University, Fort Collins, CO. 133 pp.

Fannestock, J.T., and J.K. DetLing. 1999. The influence of herbivory on plant cover and species composition in the Pryor Mountain Wild Horse Range, USA. Plant Ecology 144:145-157.

Garrott, R.A., D.B. Siniff, and L.L. Eberhardt. 1991. Growth rates of feral horse populations. Journal of Wildlife Management 55:641-648.

Hanley, T.A., And K.A. Hanley. 1982. Food resource partitioning by sympatric ungulates on Great Basin rangeland. Journal of Range Management 35:152-158.

Heske, E.J., and M. Campbell. 1991. Effects of an 11year livestock exclosure on rodent and ant numbers in the Chihuahuan Desert, southeastern Arizona. Southwestern Naturalist 36:89-93.

HobBs, N.T. 1996. Modification of ecosystems by ungulates. Journal of Wildlife Management 60:19-31.

Knapp, A.K., J.M. Blair, J.M. Briggs, S.L. Collins, D.C. Hartnett, L.C. Johnson, and E.G. Towne. 1999. The keystone role of bison in North American tallgrass prairie. BioScience 49:39-50.

KNAPP, P.A. 1992. Secondary plant succession and vegetation recovery in two western Great Basin Desert ghost towns. Biological Conservation 60:81-89.

LAYCOCK, W.A. 1967. How heavy grazing and protection affect sagebrush-grass ranges. Journal of Range Management 29:206-213.

Levin, P.S., J. Ellis, R. Petrik, and M.E. Hay. 2002. Indirect effects of feral horses on estuarine communities. Conservation Biology 16:1364-1371.

LOYDI, A., AND S.M. ZALBA. 2009. Feral horses dung piles as potential invasion windows for alien plant species in natural grasslands. Plant Ecology 201:471-480.

Maschinski, J., and T.G. Whitham. 1989. The continuum of plant responses to herbivory: the influence of plant association, nutrient availability, and timing. American Naturalist 143:1-19.

McKnight, T.L. 1958. The feral burro in the United States: distribution and problems. Journal of Wildlife Management 22:163-179.

McLean, A., AND E.W. Tisdale. 1972. Recovery rate of depleted range sites under protection from grazing. Journal of Range Management 25:178-184.

MCNaughton, S.J. 1983. Compensatory plant growth as a response to herbivory. Oikos 40:329-336.

Milchunas, D.G., and W.K. Lauenroth. 1993. Quantitative effects of grazing on vegetation and soils over a global range of environments. Ecological Monographs 63:327-366.

National Academy of Sciences. 2013. Using science to improve the BLM Wild Horse and Burro Program: a way forward. The National Academies Press, Washington, DC. 436 pp.
Ostermann-Kelm, S.D., E.A. Atwill, E.S. Rubin, L.E. HENDRICKSON, AND W.M. BOYCE. 2009. Impacts of feral horses on a desert environment. BMC Ecology 9(22). Available from: http://www.biomedcentral.com/ content/pdf/14726785-9-22.pdf

Rice, B., AND M. Westoby. 1978. Vegetative responses of Great Basin shrub communities protected against jackrabbits or domestic livestock. Journal of Range Management 31:28-34.

Sala, O.E., W.J. Parton, L.A. Joyce, and W.K. Lauenroth. 1988. Primary production of the central grassland region of the United States: spatial pattern and major controls. Ecology 69:40-45.

Schoenecker, K.A., F.J. Singer, L.C. Zeigenfuss, D. Binkley, And R. Menezes. 2004. Effects of elk herbivory on vegetation and nitrogen processes. Journal of Wildlife Management 68:837-849.

SMith, M.A. 1986. Impacts of feral horse grazing on rangelands-an overview. Journal of Equine Veterinary Science 6:236-239.

Suring, L.H., M.M. RowLAND, M.J. Wisdom, L. SchuEcK, AND C.W. MEINKE. 2005. Vegetation communities. Pages 94-113 in M.J. Wisdom, M.M. Rowland, and L.H. Suring, editors, Habitat threats in the sagebrush ecosystem: methods of regional assessment and applications in the Great Basin. Alliance Communications Group, Lawrence, KS.

Tan, B., J.T. Morisette, R.E. Wolfe, F. GaO, G.A. Ederer, J. Nightingale, and J.A. Pedelty. 2011. An enhanced TIMESAT algorithm for estimating vegetation phenology metrics from MODIS data. IEEE Journal of Selected Topics in Applied Earth Observations and Remote Sensing 4(2):361-371.

[USDI] United States Department of the Interior. 1994. Hart Mountain National Antelope Refuge Final Comprehensive Conservation Plan and Environmental Impact Statement. Available from: http:// www.fws.gov/pacific/planning/main/docs/OR/ Hart\%20Mtn/ HartMountainNARcmpEIS.pdf 2012. Sheldon National Wildlife Refuge Final Comprehensive Conservation Plan and Environmental Impact Statement. Available from: http:// www.fws.gov/pacific/planning/main/docs/NV/Sheldon/ SheldonNWRFinalCCPEIS.pdf

Wassink, J.L. 1993. Mammals of the Central Rockies. Mountain Press Publishing Company, Missoula, MT.

West, N.E., E.D. Provenza, P.S. Johnson, and K. Owens. 1984. Vegetation changes after 13 years of livestock grazing exclusion on sagebrush semidesert in west central Utah. Journal of Range Management 37: 262-264.

Wisdom, M.J., M. VaVRa, J.M. Boyd, M.A. Hemstrom, A.A. AGER, And B.K. Johnson. 2006. Understanding ungulate herbivory-episodic disturbance effects on vegetation dynamics: knowledge gaps and management needs. Wildlife Society Bulletin 34:283-292.

ZaLba, S.M., And N.C. CozZani. 2004. The impact of feral horses on grassland bird communities in Argentina. Animal Conservation 7:35-44.

Received 31 October 2013 Accepted 25 July 2014 